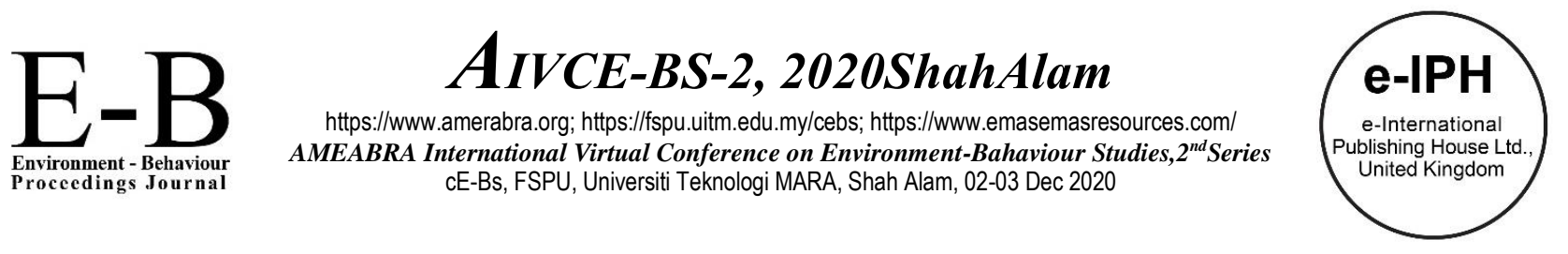

\title{
The Elderly-Friendly Housing Design Features Preferences by Generations in Malaysia
}

\author{
Hafiszah Ismail' , Muhamad Saiful Alizan Nordin², Aida Wati Zainan Abidin³ \\ $1{ }^{2}$ Centre of Studies for Estate Management, Faculty of Architecture, Planning and Surveying, \\ Universiti Teknologi MARA (UiTM), 40450 Shah Alam, Selangor, Malaysia \\ ${ }^{3}$ Centre of Studies for Statistical and Decision Science, Faculty of Computer and Mathematical Sciences, \\ Universiti Teknologi MARA (UiTM), 40450 Shah Alam, Selangor, Malaysia \\ hafiszah@uitm.edu.my,saifulalizan@uitm.edu.my,aida@tmsk.edu.my \\ Tel. : +603-5544 4285
}

\begin{abstract}
The continual increase of the elderly population will render Malaysia with an ageing nation status by 2030. However, less emphasise was taken to accommodate the needs and preferences. This study aims to provide a comprehensive overview of the Elderly-Friendly Housing Design Features Preferences among Malaysians by using the mixed-method research strategy. Six (6) identified elderly-friendly housing design features preferences were; (1) Bathroom; (2) Bedroom; (3) Kitchen; (4) Floor; (5) Living Room; and (6) Staircase. The revealed findings will assist the industry in understanding the elderly housing needs and preferences better to enhance the quality of life of the Malaysian generations.
\end{abstract}

Keyword: Elderly (Senior) Generation, Elderly-friendly housing, Elderly-Friendly Housing Design Features

eISSN: 2398-42870 2020. The Authors. Published for AMER ABRA cE-Bs by e-International Publishing House, Ltd., UK. This is an open access article under the CC BYNC-ND license (http://creativecommons.org/licenses/by-nc-nd/4.0). Peer-review under responsibility of AMER (Association of Malaysian Environment-Behaviour Researchers), ABRA (Association of Behavioural Researchers on Asians) and cE-Bs (Centre for Environment-Behaviour Studies), Faculty of Architecture, Planning \& Surveying, Universiti Teknologi MARA, Malaysia. DOI: https://doi.org/10.21834/ebpj.v5i15.2510.

\subsection{Introduction}

The continuous growth of the elderly population will render Malaysia with an ageing nation status by the year 2030. The population projection by The Department of Statistics, Malaysia displayed that by 2030 , the elderly population would escalate up to 15 percent out of the overall population in Malaysia (Hamid et al., 2013; Sulaiman, 2011). The increasing elderly group and soon retirement group among the Malaysian population should be interpreted as an important segment to be taken into consideration by policymakers in this country, for such trend will have long-term implications towards the national economics. Although, there were studies on the elderly and ageing, a fixed and definite age used in defining the 'elderly' is yet to be established (Lim, 2012; Tinker, Ginn \& Ribe et al., 2013; Yusnani, 2006). The primary definition is by referring to The World Health Organization (2012) termed the elderly as the population aged 60 years and older. In the Malaysian context, "60 years and over" of age group are used as the cut-off point in reflecting the elderly. The elderly definition was following the United Nations World Ageing Assembly in Vienna in 1982.

Malaysians as in similar with the other Asian countries, practice the norm where the elderly live together with their children. Nonetheless, only a few studies in Malaysia has examined the preferred attributes among the Malaysian Elderly. Analyses on the elderly housing preferences, specifically on the preferred housing attributes, will provide vital information to the housing developers on the elderly housing needs. Due to the growth and increase of longevity of the elderly (senior) population in Malaysia, more emphasis on the housing needs and preferences highly needed to enhance the quality of life of the generation. Therefore, this paper aims to

eISSN: 2398-4287C 2020. The Authors. Published for AMER ABRA cE-Bs by e-International Publishing House, Ltd., UK. This is an open access article under the CC BYNC-ND license (http://creativecommons.org/licenses/by-nc-nd/4.0/). Peer-review under responsibility of AMER (Association of Malaysian Environment-Behaviour Researchers), ABRA (Association of Behavioural Researchers on Asians) and cE-Bs (Centre for Environment-Behaviour Studies), Faculty of Architecture, Planning \& Surveying, Universiti Teknologi MARA, Malaysia.

DOI: https://doi.org/10.21834/ebpj.v5i15.2510. 
provide a compressive overview of the elderly-friendly housing design features preferred by the Malaysian generations derived from a study conducted in Shah Alam, Selangor. The research objective of this paper outlined as follows; (i) to define generations; and (ii) To determine the elderly-friendly housing design feature needs and preferences.

\subsection{The Generations and The Elderly Needs}

The term population refers to the generations; the group of people categorised according to the year they were born or based on the age groups (Ismail, 2019). The generational is a concept which is referring to a group of individuals that have similar characteristics especially by the birth years, experiences, thoughts, attitudes, values, beliefs and behaviours are affected by various factors, and who affects those factors in turn (Kupperschmidt, 2000; Johnson \& Johnson, 2010). There were few names given to the generation based on the year they were born. Ismail et al., (2019) classify the generations into four (4) main categories, namely the Baby Boomers (born in 1946-1961), Generation X (born in 1962-1976), Generation Y (born in 1977-1999) and Generation Z (born after 1999). Studies on generational differences in various aspect commenced in understanding better the decision-making of different age group or generations. The difference arises since different generations accompanied with different needs and preferences due to each distinct characteristics.

The present research on the elderly mainly studies three (3) angles; physiology, psychology, and sociology. The physiological and psychological aspects mainly look at the old age physiological and psychological problems-the sociology emphases mostly on the social behaviour problems of ageing. The former hierarchical model of the elderly needs projects the elderly service needs model from the user-centred perspective (Yuqi \& Ryoichib, 2019) (Figure 1).

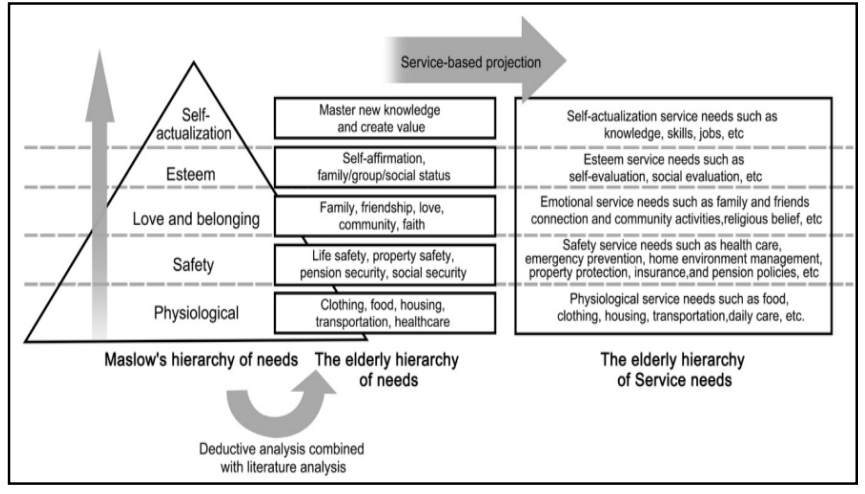

Fig. 1: The analysis process of the elderly service needs model (Yuqi \& Ryoichib, 2019)

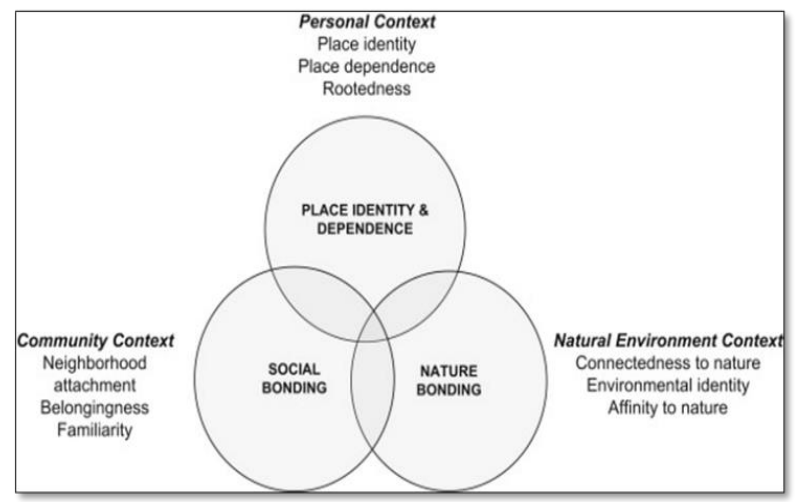

Fig.2: Three-Pole Model of Place Attachment Source: Raymond et al. (2010)

A home or a house can meet the needs of its residents (Demirbilek and Demirkan 2004). The older adult tends to remain or stay at their home and community as long as possible independently. This tendency to remain in the same place 'forever' is known as ageing in place (Bamzar, 2019). Current definitions equate place with ageing in ones' house or apartment over ones' entire life or latter years (Weil, 2015). The concept of ageing-in-place developed in studies on those who desire to age-in-place, interrelated with the reasons older persons want to stay in their current places. Ageing in place is a terminology used by gerontologists to indicate the state where an elderly (seniors) stay and remain living within the community alongside some level of independence compared to living in residential care (Wiles et al., 2011). Raymond et al. (2010) developed a Three-Pole Model of Place Attachment (Fig.2). The model view place attachment associated with three (3) basic form, which are place identity and dependence, social bonding and nature bonding. The first form is a personal aspect, which refers to placed identity and dependence and rootedness. This form, followed by the second form of social bonding associated with community context comprising neighbourhood attachment, belongingness, and familiarity. The third form is nature bonding, linked to connectedness to nature, environmental identity, and affinity to nature.

\subsection{Ageing-In-Place, Active Ageing and The Elderly Quality of Life}

There were also claims that people would prefer to age-in-place. Nonetheless, as for the older adults in specific ageing in place, the preference to stay in their home and local community for as long as possible (Keenan, 2010; Löfqvist et al., 2013). The majority of older people want to age-in-place, remain autonomous, active, and independent for as long as possible and live at home surrounded by family and friends (AARP 2011; Rantz et al. 2005). Having people stay in their homes and communities for as long as possible also avoids the costly option of institutional care and therefore favoured by policymakers, health providers, and by many older people themselves. The literature on ageing-in-place is often about how the home can be made more functional and less risky for older adults by providing various home aids to help with multiple sides of daily life. The notion is that as older people become increasingly frail or chronically ill, they can safely remain in their homes as long as they have appropriate support and services (lecovich, 2014).

The critical matter of seniors is the quality of life in their old age life stage. The fundamental of housing is not only due to the older person need for a secure and comfortable home. Housing also offers social surroundings for older people to interact with society and the community. Planning efforts on the housing of an ageing population are one of the most significant challenges faced by many countries. Numerous elderly housing studies conducted internationally with the awareness of the importance of the elderly in the community. The understanding of the diversities on the elderly requires a detailed exploration in various aspects. In Malaysia, the elderly 
housing needs and aspirations are often either neglected or not given proper emphasis. Lim (2012) suggested that critical knowledge of unique issues concerning the needs and desires of the elderly is crucial. The understanding is vital to improve the existing elderly housing policy and framework for better housing provision. Malaysia is a multiracial country, and this resulted from specific criteria for aged care service delivery and required a comprehensive assessment in meeting the needs and aspirations of the current and future elderly community (Lim, 2012). Many countries, such as the United Kingdom, Australia, Hong Kong, and Singapore, have earlier incorporated the elderly (seniors) strategies in the housing provisions. The Government mostly had practised fulfilling the elderly (seniors) needs in each of the housing development. Garin et al. (2014), pointed out that research focusing on older people and the built environment is relatively recent. Amiri (2018), highlighted the need for further emphasis on the provisions of the elderly housing facilities. Age-friendly of build environment will encourage active ageing, and thus improve the quality of life as people aged (WHO, 2007). The trend of active ageing is a significant change for the elderly.

Active ageing is a common term in several countries as in Japan, United Kingdom (UK), and United States of America (US). The countries appreciate their seniors and the elderly contributions towards the social, economic, and physical aspects for national development (Jumadi et al., 2019). The idea of an age-friendly city was promoted through the WHO's active ageing framework (WHO, 2007). Active ageing is a concept related to optimising opportunities for health, participation, and security to enhance the quality of life as people age. Active ageing depends on a variety of determinants that infold individuals, families, and also nations. WHO categorised active ageing based on six (6) elements, which are health and social services determinant, behavioural determinant, personal determinant, physical environment determinant, social determinant, and economic determinant (Lai, Lein, Lau, \& Lai, 2016). As with the elements of Active Ageing, eight (8) aspects of city life were formulated by WHO in 2007. The aspects assumed to function as coincide and interrelate model. The idea of respect and social inclusion in Active Ageing concept translated in the accessibility of the buildings and spaces, range of opportunities the city offers to older people for social participation, entertainment, or employment. Active Ageing concept requires a lifelong process, and an age-friendly city is not just 'elderly-friendly'.

Succesful housing design can also assist the elderly live in their house independently (Bhatt, 2015). Engineer et al. (2018) stressed on the importance of careful consideration in designing the elements and features in interior environments that support independence, autonomy, and health for the elderly. Design influences several features of the wellbeing of older people to well age-in-place. Bamzar (2019) emphasises the importance of the physical feature design of the living environment and assistive products in either maintaining or decreasing the independence of older persons. Jancz and Trojanek (2020) classified the preferred form of residence of the seniors and pre-seniors as follows; (1) existing apartment converted following the needs of an older person (architectural facilities); (2) a new apartment from the developer in a multi-family building meeting the needs of an older person (architectural facilitation) living in a building where there are only apartments for the elderly without additional services; (3) an apartment in a building which contains only apartments for the elderly with additional services; (4) a terraced house or a single-family house adapted for living by an elderly person; (5)a higher standard apartment (apartment) adapted to be inhabited by an elderly person; (6) shared rooms in a nursing home; and (7) independent nursing home.

\subsection{Housing Design Guidance in Malaysia - MS118 and The Universal Design Concept}

In Malaysia, currently, there is no specific Rules and Regulations for the design of Elderly-Friendly housing. However, there are two (2) main guidance and design concept used by the architects for the design of building for the Person with Disability (PWDA). The guidance is referring to MS1184 and with the adaption of the Universal Design Concept. MS1184 expected to be of benefit to all people, including; a) people with hearing impairments; b) people with visual impairments; c) People with mobility impairments; d) people with cognitive/learning impairments; e) people with hidden (such as strength, stamina, mental, dexterity and allergy; and f) People with diversities in age and structure (including frail persons).

Table 1: The Key Principles of Universal Design (UD)

\begin{tabular}{|c|c|}
\hline Principle & Description \\
\hline Equitable Use & The design is useful and marketable to people with diverse abilities \\
\hline Simple and Intuitive Use & The design accommodates a wide range of individual preferences and abilities \\
\hline Perceptible Information & $\begin{array}{l}\text { The use of the design is easy to understand, regardless of the user's experience, knowledge, language skills, or current } \\
\text { concentration level }\end{array}$ \\
\hline Tolerance for Error & The design provides necessary information effectively to the user, regardless of ambient conditions or the user's sensory abilities \\
\hline Low Physical Effort & The design can be used effectively, comfortably and minimises fatigue. \\
\hline $\begin{array}{l}\text { Size and Space for } \\
\text { Approach and Use }\end{array}$ & Appropriate size and space is provided for approach, reach, manipulation and use regardless of user's body size, posture or mobility. \\
\hline
\end{tabular}

Source: Kamarudin et al. (2014)

The adaptation of the UD in Malaysia is in line with other developed countries in delivering efficient access and facilities for all users. The main aim of the UD is design for the usage of all or to promote design that does not discriminate people based on different abilities (Kamarudin et al.,2014). The key principles of the UD listed in Table 1.3. As for housing in specific, the twelve (12) main items of the Universal Design features to improve existing homes are; (1) Entrances; (2) Doors; (3) Kitchens; (4) Bathrooms; (5) Laundry Areas; (6) Clothes Closets; (7) Interior Stairs; (8) Windows; (9) Interior Floor Surfaces; (10) Controls and Signals; (11) Decks and Patios; and (12) Parking and Walks. 


\subsection{Elderly-Friendly Housing Design Needs Considerations}

A pleasant living environment is crucial to guarantee a good quality of life of the elderly (senior) generation. The design of the housing is vital to allow the older generation or the elderly to perform their normal daily activities safely. Chen (2017) highlighted the loss of the physiological ability in all design considerations and the crucial needs for elderly-friendly housing design. Detail consideration on elderlyfriendly housing design, according to Chen (2017) can be summarised as the consideration for; (i) Privacy; (ii) Social Interaction; (iii) Clear Direction and Logo System; (iv) Security and Comfort.

\subsection{Methodology}

This study adopts mixed-methods strategy via qualitative and quantitative approaches with Shah Alam, Selangor as the case study. The choice of Shah Alam as a case study due to its status as the second City Council in Selangor. Studies on mixed technique designed to collect, analyse and mix quantitative and qualitative data in a single review or series of studies to understand a study issue (Creswell, 2009; Creswell and Plano Clark, 2007). This study encompasses interviews with the main parties and experts involved in housing development. The interviews provide the study with findings on the presence of any elderly-friendly housing design guidelines in Malaysian practice. The commenced survey questionnaires provide main suggestions of preferred elderly (senior) housing design features by the Malaysian generations. The adaptation of mixed methods in this study considered as the best method to be used. The mixed-method provides benefits that provide a better knowledge of study issues than either strategy alone Cresswell (2009). Sekaran and Bougie (2013) listed three (3) types of data collection are; interviews, administering questionnaires and observing people or phenomenon. The three (3) main data collection methods for this study comprises of; (i) interviews (21 experts \& practitioners - i.e. architects, registered town and country planner, and academicians); (ii) questionnaire administration (338 samples - i.e. the housing consumers by generations under the area of City Council of Shah, Alam); and (iii) observation of people and phenomena (i.e. housing development project representing multi-generational housing concept - TUAI RESIDENCE, in Setia Alam and Retirement Village GreenAcres, Ipoh). Total numbers of 338 samples from the survey questionnaires (via Google-Form and printed survey) managed to be collected by using snowball sampling together with the assistance of enumerators for the collection of the responses. However, this paper will only discuss the quantitative findings of the study. The findings derived will be usable for the housing developments in Malaysia and not in specific for landed or stratified housing.

\subsection{Results, Findings and Discussions}

As for the ageing or senior types of housing options (Table 2), in overall more than half of the Malaysian generations would like to remain in the same house or same location or ageing in place $(52.4 \%)$. The other $31.4 \%$ of respondents would like to move to other locations and live with the family members, and $10.4 \%$ wished to move to other location and live independently. Moreover, the most preferred types of elderly housing options are single-family housing; conventional housing $(76.0 \%)$, as portrayed in Table 3 . Retirement/agerestricted community with healthcare services $(24.2 \%)$ is followed by living in the community without healthcare services $(0.4 \%)$.

Table 2. Housing Choice Preferred Most for the Age of 60

\begin{tabular}{|c|c|c|c|}
\hline Variable & Category & Frequency & $\%$ \\
\hline & Ageing in place & 177 & 52.4 \\
\hline $\begin{array}{l}\text { Housing } \\
\text { choice }\end{array}$ & $\begin{array}{l}\text { Move to other location and live } \\
\text { on your own }\end{array}$ & 35 & 10.4 \\
\hline $\begin{array}{l}\text { preferred } \\
\text { most for }\end{array}$ & $\begin{array}{l}\text { Move to other location \& live } \\
\text { with family members }\end{array}$ & 106 & 31.4 \\
\hline \multirow[t]{2}{*}{$\begin{array}{l}\text { the age of } \\
\quad 60\end{array}$} & $\begin{array}{l}\text { Move to other types of housing } \\
\text { especially for the elderly }\end{array}$ & 15 & 4.4 \\
\hline & Others & 5 & 1.5 \\
\hline
\end{tabular}

Table 3. Types of Elderly Housing Options

\begin{tabular}{clcc}
\hline Variable & Category & Frequency & $\%$ \\
\hline & Single-family housing & 257 & 76.0 \\
\cline { 2 - 4 } & Retirement/Age-Restricted & 75 & 22.2 \\
Types of & Community & & \\
elderly & $\quad$ with healthcare services & 68 & 24.2 \\
housing & $\quad$ without healthcare & 1 & 0.4 \\
options & $\quad$ services & & \\
\cline { 2 - 4 } & Nursing home & 4 & 1.2 \\
& Others & 1 & 0.3 \\
\hline
\end{tabular}

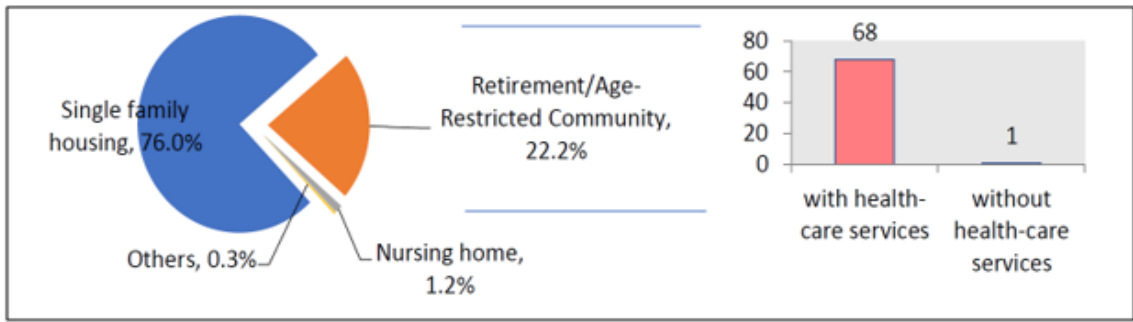

Fig.3. Percentage and Frequency of Types of Elderly Housing Options

The results indicated the Malaysian generations (Baby Boomers, Gen-X, and Gen-Y) prefer to age in place and live independently but willing to move if they have. The preferences to age in place by the Malaysian generations is in line with the 'Three-Pole Model of Place Attachment' by Raymond et al., (2010). The high preference for Retirement/Age-Restricted Community with healthcare services shows the elderly (senior) service need for safety service needs (in line with the elderly service needs model by Yuqi \& Ryoichib, 2019). 
Table 4 shows a list of the specific form of elderly-friendly housing preference for the age of 60 . The respondents' most preferred form of elderly housing is an existing housing unit/apartment converted for the needs of the elderly (48.4\%). The other respondents preferred a new housing unit from the developer $(20.2 \%)$, especially in a multi-generational building which also meets the needs of an elderly in term of architectural facilities. A few other of the respondents preferred terraced house or single-family house adapted for elderly (17.8\%). The least preferred form of elderly-friendly housing is to be living in a building of housing for the elderly but without the additional services $(2.4 \%)$. The generations' high preference for their existing housing to be converted with Elderly-Friendly Housing Concept is in line with their preference to age in place.

Table 4. Specific Form of Elderly-Friendly Housing Preferred

\begin{tabular}{clcc}
\hline Variable & Category & Frequency & Percentage \\
\hline \multirow{2}{*}{ The specific } & Existing housing unit/apartment converted & 163 & 48.4 \\
form of & A new housing unit from the developer & 68 & 20.2 \\
ELDERLY- & Building for only housing the elderly without additional services & 8 & 2.4 \\
FRIENDLY & A housing unit for the elderly with additional services & 22 & 6.5 \\
HOUSING & A terraced house or single-family house adapted for elderly & 60 & 17.8 \\
preferred & A higher standard apartment adapted to be inhabited for the elderly & 12 & 3.6 \\
& Others & 4 & 1.2 \\
\hline
\end{tabular}

In term of familiarity as in certain local traditions and placement of familiar personal items in designing elderly-friendly housing features, the bathroom design was ranked as the most familiar design (74.5) as in Table 5, which calculated from the score assigned by the panels. These were followed by the design of the bedroom (70.7), kitchen (69.0), living room (67.6), and the floor design (67.3). The panels showed the least familiarity in the staircase feature (66.6) as in designing elderly-friendly housing. The comparison between familiarity and preferences on the Elderly-Friendly housing design shows the Malaysian generation were aware of the importance of elderly-friendly housing design for each specific dwelling unit.

Table 5. Index of Familiarity for Features of Elderly-Friendly Housing Design

\begin{tabular}{|l|c|c|}
\hline \multicolumn{3}{|c|}{ FAMILIARITY } \\
\hline Housing Design Features & Index & $\begin{array}{c}\text { Order of } \\
\text { Familiarity }\end{array}$ \\
\hline Elderly-Friendly BATHROOM Design & 74.5 & 1 \\
Elderly-Friendly BEDROOM Design & 70.7 & 2 \\
Elderly-Friendly KITCHEN Design & 69.0 & 3 \\
Elderly-Friendly LIVING ROOM Design & 67.6 & 4 \\
Elderly-Friendly FLOOR Design & 67.3 & 5 \\
Elderly-Friendly STAIRCASE Design & 66.6 & 6 \\
\hline
\end{tabular}

Table 6. Index of Preferences for Features of Elderly-Friendly Housing Design

\begin{tabular}{|l|c|c|}
\hline \multicolumn{3}{|c|}{ PREFERENCE } \\
\hline Housing Design Features & Index & $\begin{array}{c}\text { Order of } \\
\text { Preferences }\end{array}$ \\
\hline Elderly-Friendly BATHROOM Design & 85.0 & 1 \\
Elderly-Friendly BEDROOM Design & 82.1 & 2 \\
Elderly-Friendly KITCHEN Design & 82.0 & 3 \\
Elderly-Friendly FLOOR Design & 80.5 & 4 \\
Elderly-Friendly LIVING ROOM Design & 80.0 & 5 \\
Elderly-Friendly STAIRCASE Design & 76.0 & 6 \\
\hline
\end{tabular}

Other than that, the respondents once again emphasised bathroom design as the most preferred feature (85.0) when designing the elderly-friendly housing as in Table 6. The second preferred feature chosen by the panels was the bedroom design (82.1) followed the kitchen design (82.0), floor design (80.5) and living room design (80.0). However, staircase design was the least preferred feature (76.0) when designing an elderly-housing unit.

Table 7. Index of Importance for Elderly-Friendly Housing Design Features Preferences based on Generation Year Born

\begin{tabular}{|c|l|c|c|c|c|c|c|}
\hline \multirow{3}{*}{$\begin{array}{c}\text { MAIN } \\
\text { FEATURE }\end{array}$} & FEATURES & \multicolumn{2}{|c|}{$\begin{array}{c}\text { Born 1946 - 1961 } \\
\text { (Baby Boomers) }\end{array}$} & \multicolumn{2}{|c|}{$\begin{array}{c}\text { Born 1962 - 1976 } \\
\text { (Generation X) }\end{array}$} & \multicolumn{2}{|c|}{$\begin{array}{c}\text { Born 1977 - 1991 } \\
\text { (Generation Y) }\end{array}$} \\
\cline { 3 - 8 } & & Index & $\begin{array}{c}\text { Order of } \\
\text { importance }\end{array}$ & Index & $\begin{array}{c}\text { Order of } \\
\text { importance }\end{array}$ & Index & $\begin{array}{c}\text { Order of } \\
\text { importance }\end{array}$ \\
\hline \multirow{4}{*}{$\begin{array}{c}\text { Housing } \\
\text { Design }\end{array}$} & Elderly-Friendly STAIRCASE Design & 79.6 & 6 & 75.6 & 6 & 76.1 & 6 \\
\cline { 2 - 8 } & Elderly-Friendly FLOOR Design & 81.5 & 3 & 79.9 & 4 & 81.7 & 4 \\
\cline { 2 - 8 } & Elderly-Friendly LIVING ROOM Design & 80.0 & 5 & 78.4 & 5 & 78.6 & 5 \\
\cline { 2 - 8 } & Elderly-Friendly BATHROOM Design & 88.5 & 1 & 86.8 & 1 & 90.2 & 1 \\
\cline { 2 - 8 } & Elderly-Friendly KITCHEN Design & 81.2 & 4 & 81.5 & 3 & 82.3 & 3 \\
\cline { 2 - 8 } & Elderly-Friendly BEDROOM Design & 84.2 & 2 & 84.1 & 2 & 84.9 & 2 \\
\hline
\end{tabular}

Table 7 shows the index of importance for elderly-friendly housing design features preferences by generations. Majority of Baby Boomers generation, Generation X and Generation $Y$ perceived elderly-friendly bathroom and bedroom as their $1^{\text {st }}$ and $2^{\text {nd }}$ preferred elderly-friendly housing design features. The differences in preferences found in the $3^{\text {rd }}$ and $4^{\text {th }}$ preferred features. Here, we can see that the Baby Boomers regards the elderly-friendly floor as their $3^{\text {rd }}$ preferred design preferences. Generation $X$ and $Y$ both regard elderly-friendly kitchen as $3^{\text {rd }}$ preferred features. In contrast, Baby Boomers regard the kitchen as their $4^{\text {th }}$ preferred housing design features. The Baby Boomers, Generation X, Generation $Y$ and Generation both in agreement to view living room and staircase as their $5^{\text {th }}$ and $6^{\text {th }}$ preferred features. The highest-ranked preferred design features made on the bathroom is since this area has the highest risk of falling by the elderly (senior) generations without provision of the elderly-friendly design features on the housing unit. The fact that the bathroom (ranked 1 st preferred) and bedroom (ranked $2^{\text {nd }}$ preferred) was regarded as the most preferred elderly-friendly design 
features by the Malaysian generations provide information to the housing providers to consider these features as the main features in future elderly-friendly development in Malaysia.

\subsection{Conclusion and Recommendations}

The increasing numbers of the elderly population with expands of life age up to nearly 80 years old have resulted in all sectors worldwide to start focussing on this generation, and this includes the housing segments in particular. The growth of the ageing population and their high purchasing power will in the future make them one of the most important customer groups and a decisive driver for the success of companies in many industrial sectors (Bloom et al., 2010). The elderly (seniors) generations or the 'grey hair' consumers is unique and equipped with distinct needs and preferences.

The typical age-related health problems affect common habitual actions of the elderly (senior) and thus resulted in the needs for elderly-friendly design consideration. In overall, this study reveals the Malaysian generations prefers to age-in-place and live independently in their retirement life stage. However, the generations are also willing to move to another location and live with family members if they have to do so. The main reason for the elderly mobility housing decision is due to the health condition, or the late-life moves due to the need for assistance by the elderly (senior) in performing daily life activities. Family/family members and spouse/partner/husband or wife perceived as the primary influence of the elderly (senior) housing selection decision-making. Most importantly, the study uncovers the two (2) prime preferred forms of elderly-friendly housing are such as; (i) existing housing unit/apartment converted; and (ii) a new housing unit from the developer. Most importantly, the generations indicate a high level of familiarity on the elderly-friendly housing design features. The preferred elderly-friendly housing design features among the Malaysian generations are; (1) bathroom; (2) bedroom; (3) kitchen; (4) living room; (5) floor; and (6) staircase.

Despite the growing numbers of the elderly (senior) population, currently, in Malaysia, there is no compulsory requirement for every housing development to be embedded with elderly-friendly design features. The compulsory action is vital to guarantee the excellent quality of life of all Malaysian generations through active ageing. The Government should make a rigorous promotion of elderly-friendly housing as the provision of elderly-friendly housing is vital and significant in addressing the Malaysian ageing population's social issues. Proper and specifically tailored choices of elderly housing provision may reduce the burden of cost to the Government in providing a healthcare system for the elderly (seniors) in Malaysia. In addition, a continuous effort among property players via large scale engagement by both public and private sectors are highly in need by way of promoting indigenous elderly-friendly housing design and the ability to penetrate the housing market segmentation. Clear housing policies and guidelines on quota requirements in a selected housing development or housing concept can help trigger support for elderly-friendly housing provisions by the private sectors. An incentive tax exemptions can be introduced to the developers undertaking elderly housing development in making such development more competitive. Finally, the high preference of the elderly-friendly housing design features shows the awareness of the elderly (senior) generation on the importance of housing design that would affect the quality of life of the Malaysian generation. New housing concept such as the Multi-Generation/Extended Housing Concept is the best housing concept for elderly-friendly housing design features embedment. This new housing concept will be able to promote the social inclusion of both younger and older generations in one housing unit with an independent living arrangement. The Multi-Generational Housing Concept in the Malaysian context is seen as the most suitable housing concept to be embedded with elderly-friendly housing design features. This study provides some input of the preferred elderly-friendly housing design features by the Malaysian generations. Further research can be conduct on determining the design features in specific for landed and also stratified housing in Malaysia. A study on the elderly-friendly housing concept through 'waqf' land development that will also be significant for the Malaysian real estate market.

\section{Acknowledgements}

The authors would like to express our gratitude and to thank The Ministry of Finance, Malaysia, on the award of funding for this study under the NAPREC Research Grant 2019/2020 [NAPREC (R\&D) 15/19].

\section{Paper Contribution to Related Field of Study}

This paper provides a comprehensive overview of the preferred features of Elderly-Friendly Housing Design Features that contributes to the enhancement of the quality of life of the Malaysian ageing generation in Malaysia.

\section{References}

AARP (American Association of Retired People) (2011). Ageing in place: A state survey of livability policies and practices. Retrieved from https://assets.aarp.org/rgcenter/ppi/liv-com/aging-in-place-2011-full.pdf

Amiri, M. (2018). Problems faced by old age people. The International Journal of Indian Psychology, 6(3), $52-62$.

Bamzar, R. (2019). Assessing the quality of the indoor environment of senior housing for a better mobility: a Swedish case study. Journal of Housing and the Built Environment, 34(1), 23-60.

Bhatt, H. (2015). Biophilic Design for the Elderly: Design of a Senior Living Community Along the Delaware. Thesis. Philadelphia University, Philadelphia. 146 
Bloom, D. E., Canning, D., \& Fink, G. (2010). Implications of population ageing for economic growth. Oxford Review Of Economic Policy, 26(4), 583-612.

Chen, K. (2017). Sustainable Design For The Elderly: Senior Housing Design Guidelines. Master's Thesis. University of Florida, Florida.

Creswell, J. W. (2009). Mapping the field of mixed methods research. Journal of Mixed Methods Research, 3(2), 95-108.

Creswell, J. W. and V. L. Plano Clark. (2007). Designing and Conducting Mixed Methods Research. Thousand Oaks: Sage Publications.

Demirbilek, O., \& Demirkan, H. (2004). Universal product design involving elderly users: A participatory design model. Applied Ergonomics, 35(4), 361-370.

Engineer, A., Sternberg, E. M., \& Najafi, B. (2018). Designing interiors to mitigate physical and cognitive deficits related to aging and to promote longevity in older adults: a review. Gerontology, 64(6), 612-622.

Garin, N., Alaya, B., Miret, M., Ayuso-Mateos J.L., Power, M., Bucciarelli, P. and Haro, J.P. (2014). Built environment and elderly population health: A comprehensive literature review. Clinical Practice \& Epidemiology in Mental Health, 10, 103-115

Hamid, T. A, Momtaz, Y. A., Ibrahim, R., Mansor, M., Abu Samah, A., Yahaya, N., and Abdullah, S. F. Z. (2013). Development and psychometric properties of the Malaysian elder abuse scale. Open Journal of Psychiatry. 3, 283-289. doi:10.4236/ojpsych.2013.33027

lecovich, E. (2014). Aging in place: From theory to practice. Anthropological Notebooks, 20(1), 21-33.

Ismail, H. (2019). Housing decision: the choice between location, house and neighbourhood among Malaysian generations. MATEC Web of Conferences 266(6):01026. DOI:10.1051/matecconf/201926601026

Ismail. H, Aziz, F. and Wahab, A., M. (2019). The Elderly (Senior) Housing Options Preferences Among Malaysian Generations. IOP Conference Series: Earth and Environmental Science, Volume 385, 4th International Conference on Research Methodology for Built Environment and Engineering $201924-25$ April 2019 , Chulalongkorn University, Malaysia

Jancz, A., \& Trojanek, R. (2020). Housing preferences of seniors and pre-senior citizens in poland—A case study. Sustainability, 12(11), 4599.

Johnson, M., \& Johnson, L. (2010). Generations, Inc.: From boomers to Linksters - managing the friction between generations at work. New York, NY: AMACOM.

Jumadi, N., M.Noor, N.A, Bujang, A.A, A.Maimun, N.H, Daud, D., W. Ismail, W.I.F, M.Yusoff, N.S, \& A. Rahman, M.S (2019). Active ageing and housing environment concept among elderly Muslims. Journal of the Malaysian Institute of Planners, 17(1), $305-318$.

Kamarudin, H., Muhamad Ariff N. R., Wan Ismail, W. Z., Bakri, A.F., and Ithnin, Z., (2014). Malaysian Scenario on Access and Facilities for Persons with Disabilities: A literature review. Building Surveying, Facilities Management and Engineering Conference (BSFMEC 2014). http://www.matec-conferences.org or http://dx.doi.org/10.1051/matecconf/20141501019

Keenan, T. A. (2010). Home and community preferences of the 45+ population. Washington, DC: AARP Research \& Strategic Analysis.

Kupperschmidt, B.R. (2000) Multigeneration employees: strategies for effective management. The Health Care Manager, 19, 65-76.

Lai, M. M., Lein, S. Y., Lau, S. H., \& Lai, M. L. (2016). Modelling age-friendly environment, active ageing, and social connectedness in an emerging Asian economy. Journal of Ageing Research, 2016, 1-14.

Lim, C. K. (2012). The changing needs of older Malaysians: a Selangor case study.(Doctoral dissertation, Adelaide: University of Adelaide).

Löfqvist, C., Granbom, M., Himmelsbach, I., Iwarsson, S., Oswald, F. \& Haak, M. (2013). Voices on relocation and ageing in place in very old age—a complex and ambivalent matter. The Gerontologist, 53(6), 919-927.

Rantz, M. J., Marek, K. D., Aud, M. A., Johnson, R. A., Otto, D., \& Porter, R. (2005). TigerPlace: A new future for older adults. Journal of Nursing Care Quality, 20(1), $1-4$.

Raymond, C. M., Brown G. \& Weber D. (2010). The measurement of place attachment: Personal, community, and environmental Connections. Journal of Environmental Psychology, 30(2010), 422-434.

Sekaran, U., \& Bougie, R. (2013). Research methods for business: A skill building approach (6th ed.). Chichester: John Wiley \& Sons Ltd.

Sulaiman, N. (2011). Opportunities for the transfer of United Kingdom best practices for the provision of public residential care facilities for the elderly to Malaysia (Doctoral dissertation, Salford: University of Salford).

Tinker, A., Ginn, J., and Ribe, E. (2013). Assisted Living Platform: The Long Term Care Revolution: a Study of Innovatory Models to Support Older People with Disabilities in the Netherlands. King's College London.

Weil, J. (2015), "Ageing in place in many places: new directions in navigating home", Keynote Speech, $4^{\text {th }}$ Annual Create Our Future Together Conference (COFT), Boulder County Area Agency on Ageing (AAA), October 30

Wiles, J.L., Leibing, A., Guberman, N., Reeve, J., Allen, R.E (2011). The meaning of "ageing in place" to older people. Gerontologist, 52(3), 357-366. World Health Organization (WHO) (2007). Global Age-Friendly Cities: A Guide, Geneva, Switzerland. Retrieved from http://www.who.int/ageing/publications/Global_age_friendly_cities_Guide_English.pdf

World Health Organization (WHO) (2012). World report on Ageing and Health. Retrieved from 9789240694811_eng.pdf;jsessionid+3C0D125869B3BAAF6ACEEF51A671E9B.pdf on November 22, 2020. 
Ismail, H., et.al., AIVCE-BS-2, 2020ShahAlam, cE-Bs, FSPU, Universiti Teknologi MARA, Shah Alam, Malaysia, 02-03 Dec 2020, E-BPJ, 5(15), Dec 2020 (pp.141-148)

Yuqi, L., and Ryoichib, T. (2019). Study on the Model of the Elderly's Service Needs of Smart Home: Construction and Application. International Association of Societies of Design Research Conference 2019. Manchester School of Art Manchester Metropolitan University. pp. 1-8.

Yusnani, M. Y. (2006). Accommodating the Malaysian elderly: the cultural precursors. Ageing International, 31(3), 185- 202. Retrieved from UQ eSpace database. 